adviser to the Government of India. The same year he returned to England as director of the Imperial Bureau of Mycology; and in 1921, his services to India were recognized with the C.I.E.

While still in Europe, Butler had commenced his study of the genus Pythium, and became an adept at isolating its species from the soil; his monograph on the genus was published in India in 1907, and is still in great demand. His special interest in the Phycomycetes, for example, Phytophthora, Sclerospora, and Rhizophagus remained to the end. At Calcutta he was introduced to the fungi of the agricultural crops ; at Dehra Dun to the forest fungi, especially as they attack tree roots, and at Pusa finally became committed to crop fungi, which were then poorly known. A ubiquitous weed Launcea asplenifolia was a reputed alternate host for Indian brown rust of wheat; its rust, however, proved to be autocious, and Puccinia butleri Sydow commemorates one of his first tasks. Monographs on sugar-cane diseases, wheat rusts (with Hayman), Fusarium wilts, Sclerospora disease, and rice diseases, including one caused by an eelworm, were among his special publications. Five papers on the micro-fungi of India, jointly with H. and P. Sydow, covered the Indian rusts, smuts, Phycomycetes, Ascomycetes, and Colomycetes, many new records being based upon his own collections. In 1918, with the publication of his "Fungi and Disease in Plants", he established an international reputation as a plant pathologist. To round off his work on Indian mycology, in 1932 he published, jointly with G. R. Bisby, "The Fungi of India", a compilation of the species recorded up to 1930 , and of their literature.

The year 1921 was mainly spent in organizing the new Bureau; but during a two months visit to America, Butler established cordial relationships with numerous mycologists and plant pathologists, and secured their goodwill for his new venture. In January 1922, he brought out the first monthly part of the Review of Applied Mycology, and for many years, editing that journal had the first call upon his time. In 1923 he visited New Zealand on his way to attend the Pan-Pacific Science Congress in Australia, and again secured the goodwill of all he met; the recognition of Phytophthora hibernalis Carne as a distinct pathogen of citrus dates from that visit. In 1924 he successfully organized the first Imperial Mycological Conference. In 1926 he was elected F.R.S., and was chairman of the Mycological Section of the International Congress of Plant Sciences at Ithaca, U.S.A. In 1927 he was president of the British Mycological Society, and was invited to Nyasaland to inspect the tea plantations there ; Sclerospora butleri Weston, the type of which he collected, felicitously commemorates this visit. In 1928-29 he was president of the Association of Economic Biologists, and in 1929, the year of the second Imperial Mycological Conference, was also vice-president of the Linnean Society of London. In 1930, he was recorder of the Section for Mycology and Plant Pathology at the International Botanical Conference at Cambridge. In 1931 he was invited to the Sudan, where 200,000 acres of cotton were threatened by black-arm; in 1932 he was awarded C.M.G. ; in 1934 was elected to the Council of the Royal Society; and delivered the Lowell Lectures at Harvard University, the home of the famous Farlow Herbarium and Cryptogamic Laboratories.

During this period, Butler's published work was mainly for the occasion, and displayed his many interests. In 1926 at Ithaca, for example, his subject was the delimitation of fungus species; in 1927 the development of economic mycology in the Empire; in 1929 the morbid anatomy of plants; in 1932, to the British Association, tropical plant diseases with "every gradation of severity from the sorghum smut which levies a moderate toll of about ten per cent of the crop . . . to the Panama disease which completely exterminates the susceptible bananas and precludes replanting within any reasonable time". But through it all, his spontaneous interest in fungi as fungi, together with his genial hospitality, attracted to the Institute all sorts and conditions of mycologists. Thus in 1934 A. H. R. Buller dedicated the sixth volume of his "Researches on Fungi" to "E. J. Butler, the distinguished director of the Imperial Mycological Institute, in recognition of his contributions to our knowledge of fungi, and of his helpfulness to fellow workers."

His years of service were marked by his preeminent ability both to appreciate a situation and to state a case. Hence his advice was in constant demand in committee work both by such Government bodies as the Colonial Advisory Council of Agriculture, and such public ones as the Empire Cotton Growing Corporation. Finally, in 1935, he yielded to insistent pressure, and left the Imperial Mycological Institute, where he will long be remembered as a great chief, and became secretary to the Agricultural Research Council. In 1938 he was made LL.D. honoris causa of the University of Aberdeen. $\mathrm{He}$ was knighted in 1939 and retired for health reasons in 1941. Just before his death, he was back among the fungi again, exuberantly rewriting for a new book the first chapter of his "Fungi and Disease in Plants" in the light of the experience of another quarter of a century.

He died suddenly on April 4, following an attack of influenza: and is survived by Lady Butler, and by a son and two daughters.

E. W. Mason.

\section{Commander F. A. Worsley, D.S.O., O.B.E., R.N.R.}

Commander Worsley was born at Akaroa, New Zealand, in 1872, and died at Claygate, Surrey, in February last. At fifteen years of age he was apprenticed in sailing ships of the New Zealand Shipping Company and made his first voyage in the squarerigged Wairoa. After his apprenticeship days, he became mate and later master of Now Zealand Government schooners, among them the Tutanaki and the Countess of Ranfurly, working in the South Pacific. Afterwards he turned his attention to steam, joined the Royal Naval Reserve and had the usual training with the Grand Fleet. This was in 1908. In January 1909 he joined the Allan Line and made acquaintance during the succeeding five years with ice conditions on the Canadian route.

Worsley was appointed master of the Endurance in June 1914, and his abilities and untiring energy soon made themselves known. He was a splendid shipmaster and made an ideal combination with Shackleton. The Endurance was crushed in the ice after her adventurous voyage through the ice of the Weddell Sea and the crew then lived for six months on drifting pack-ice, until it broke up in the open sea east of Graham Land. Boats were launched and Worsley was in charge of the cutter Dudley Docker in the escape from the ice to Elephant Island. His outstanding feat was the navigation of the James 
Caird on the historic journey from Elephant Island to South Georgia. It is no exaggeration to say that Worsley's study of the winds and currents of the South Atlantic and his knack of snapping the sun, no matter how adverse the conditions, ensured the success of the voyage and ultimately the rescue of the marooned party on Elephant Island. Worsley has himself written an account of this journey under the title of "Shackleton's Boat Journey", and other incidents of the expedition are to be found in his longer book "Endurance".

On his return to Great Britain, Worsley commanded P- and Q-ships and won the D.S.O. and bar for successful operations against U-boats during the War of 1914-18. He also served on the north Russian front, advising on arctic equipment and transport. On the conclusion of hostilities he again rallied to Shackleton and became sailing master and hydrographer of the Quest in 1921. From then onwards until 1939, Worsley sailed on occasional trading vessels. During the present War his activities were many and varied, such as Red Cross work in Norway, ferrying steamers, clearing wrecks, lecturing to troops, and ultimately as instructor in seamanship at Green: wich.

Two events stand out in the inter-war period. In 1925 he was joint leader of an arctic expedition in the auxiliary sailing ship Island, which penetrated to Franz Josef Land and of which a full account is given in his "Under Sail in the Frozen North". In 1935 his love of adventure took him to Cocos Island in search of hidden treasure.

Worsley was a man of action, always on the move and extremely alert, both mentally and physically.
He retained this amazing vigour up to the very end and steadily refused to go into retirement. It was hard to believe that he had reached his three score years and ten. He was not a man of science in the strict sense of the word, but he was a born naturalist and observer, as the logs which he kept on his cruises bear out. Animal life appealed to him and he had a good working knowledge of sea birds, seals and whales. It was as a navigator, however, that he stood supreme, and there is nothing finer than his piloting of the James Caird to South Georgia, an island not much more than a speck on the wide South Atlantic Ocean.

R. S. CliarK.

NAzr air-raids and artillery bombardments of Leningrad, Moscow and other Russian cities are taking a heavy toll of the scientific workers who have remained at their posts. News has just reached Great Britain of the deaths in this way of the following entomologists : A. M. Iljinsky (specialist in insect toxicology); A. M. Gerasimov (lepidopterist); S. A. Predtechensky (specialist in Orthoptera and particularly in the locust problem); A. N. Reichardt (coleopterist, specialist in Histeridæ); V. E. Redikorzev (insect anatomist and histologist); A. A. Stackelberg (dipterist); S. P. Tarbinsky (orthopterist); "and many others" as is stated in the letter containing this sad list. All these entomologists were well-known specialists in their respective spheres, most of them in the prime of life, and these gaps in the ranks of leaders of Soviet entomology will not be easy to fill, particularly when even heavier losses can be expected among the younger entomologists serving in the Armed Forces.

\section{NEWS and VIEWS}

\section{International Relations}

IN the first Montague Burton Lecture on "International Relations" delivered at Leeds on October 9, 1942, which has now been published by the University, Mr. J. G. Winant, attempting first to answer the question, why should barbarism be so rife in our modern world, suggested that one of the reaisons was that in the years following the War of 1914-18 we neither tried to build a kindly world nor apportioned a sufficient percentage of national income to be armed effectively against aggression. Further, we did not give sufficient attention to either national or international machinery to allow the people effectively to meet social and economic needs within their own countries, or to give effective expression to the vast majority of people who wanted peace. Our consciences had also been blunted in the face of challenges to the rules of civilized life, and this slow decay of conscience occurred in a world of declining economic stability.

Our first task, said Mr. Winant, is to rebuild the moral basis of our life, neglect of which invites a revolution against the very conception of moral law. A world revolt against civilization will begin again, even after the defeat of the Axis, unless we destroy the roots of cynicism by proving in conduct our belief in justice, freedom and Christian brotherhood. We do not need a new tradition or a revolution, but only to preserve and make real in a world of action the great traditions we have inherited and which should be realized in free government and the Christian faith. We do not need a new economic system, but to learn to use the system we already possess so as best to serve our purposes. The real question is whether they serve best the ends of our society, in promoting the justice and equality of opportunity and freedom which are its purpose. We need above all to subject the machinery of life to its purpose, in place of being slaves of that machinery. Under the pressure of the terrible events of to-day, we must be great of purpose or we cannot survive. The moral and high political aims of our society must be put first, and economy machinery made their servant. We are fighting for a second chance to make the greatest of traditions come true. There is nothing to substitute for it; we must go ahead perfecting the political and moral system we have inherited or we let the system perish and the world revert to barbarism. He believes that we could build beyond nationalism an orderly international world, but nothing less than to serve our great tradition greatly would serve us in the disasters of to-day.

\section{World Waste and the Atlantic Charter}

Is a lecture on "World Waste and the Atlantic Charter" at the Union Society's Hall, Oxford (Oxford : B. H. Blackwall, Ltd.; 1s. net), Sir James Mar. chant points out that the lessening rate of discovery and the intensive use of minerals have already, inde. pendently of the increased demands due to the War, 